\title{
Potential of Stable Carbon and Oxygen Isotope Variations of Speleothems from Andaman Islands, India, for Paleomonsoon Reconstruction
}

\author{
Amzad H. Laskar, ${ }^{1}$ S. $\operatorname{Raghav}^{2}$ M. G. Yadava, ${ }^{1}$ R. A. Jani, ${ }^{1}$ A. C. Narayana, ${ }^{3}$ and R. Ramesh $^{1}$ \\ ${ }^{1}$ Geosciences Division, Physical Research Laboratory, Gujarat, Ahmedabad 380009, India \\ ${ }^{2}$ Paleontology Division, Marine Wing Geological Survey of India, Kolkata 700091, India \\ ${ }^{3}$ Centre for Earth \& Space Sciences, University of Hyderabad, Hyderabad 500046, India
}

Correspondence should be addressed to R. Ramesh, rramesh@prl.res.in

Received 31 December 2010; Revised 3 March 2011; Accepted 4 March 2011

Academic Editor: Atle Nesje

Copyright (C) 2011 Amzad H. Laskar et al. This is an open access article distributed under the Creative Commons Attribution License, which permits unrestricted use, distribution, and reproduction in any medium, provided the original work is properly cited.

The Indian monsoon activity, coinciding with the Inter-Tropical Convective Zone (ITCZ), progresses from the southern Indian Ocean during the boreal summer and withdraws towards the south in winter. Islands situated to the south of India receive, therefore, the first and last showers of the monsoon; speleothems in such islands have not yet been explored for their potential to reconstruct past monsoon rainfall. Here, we present the first measurements of stable carbon and oxygen isotopic compositions $\left(\delta^{13} \mathrm{C}\right.$ and $\left.\delta^{18} \mathrm{O}\right)$ of a stalagmite collected from the Baratang Island of Andamans, along with new data on $\delta^{18} \mathrm{O}$ of modern monsoon precipitation (May to July 2010). The aim was to detect (i) whether these samples are amenable to dating using ${ }^{14} \mathrm{C}$, (ii) whether their oxygen isotopes indicate precipitation under isotopic equilibrium, and (iii) if (i) and (ii) above are true, can we reconstruct monsoon activity during the past few millennia? Our results indicate that while $\delta^{18} \mathrm{O}$ of speleothem does show evidence for precipitation under isotopic equilibrium; dating by ${ }^{14} \mathrm{C}$ shows inversions due to varying contributions from dead carbon. The present work highlights the problems and prospects of speleothem paleomonsoon research in these islands.

\section{Introduction}

The Indian monsoon is a mesoscale weather system affecting a very densely populated area of the globe. It is important to attempt high-quality paleoclimate reconstructions for a better understanding of the monsoon. The dynamics of Indian monsoon are not well understood due to lack of highresolution and long-term monsoon records. The longest instrumental record of monsoon rainfall available spans the last $\sim 150$ years [1] and, therefore, too short to fully reveal monsoon variability on century and longer time scales, for which limited high resolution, geographically more widely distributed, paleomonsoon records based on speleothems [2-5], ice cores [6], tree-rings [7], and marine sediments [811 ] are currently available.

Speleothems are secondary carbonates precipitated in karst regions that record the paleoenvironmental changes in atmospheric circulation as the oxygen isotopic ratio $\left(\delta^{18} \mathrm{O}\right)$ of speleothems is primarily controlled by rainfall $\delta^{18} \mathrm{O}$ in the tropics [3-5], as the latter depends on the amount of rainfall (the amount effect); the $\delta^{18} \mathrm{O}$ in rain decreases with increasing amount of rainfall. On seasonal time scales, variations of $\delta^{18} \mathrm{O}$ in precipitation arise from variations in the source of rainfall and its characteristics such as the frequency, the duration, and the intensity of rain. On longer timescales (centennial to millennial), additional factors such as changes in the $\delta^{18} \mathrm{O}$ of the ocean (the ice volume effect), changes in the seasonality of precipitation (e.g., change in the relative proportions of winter and summer precipitation), and shifts in the source of moisture may be important (e.g., [12]). Despite these complications, $\delta^{18} \mathrm{O}$ of speleothem calcite is currently the most frequently used proxy as it can help reconstruct past precipitation on time scales ranging from centuries to millennia.

The carbon isotopic composition $\left(\delta^{13} \mathrm{C}\right)$ of speleothems is somewhat complicated to interpret. Nevertheless, changes 
in $\delta^{13} \mathrm{C}$ in most cases are the likely result of climate change [13], and a combined study with $\delta^{18} \mathrm{O}$ may reveal important aspects of climate and vegetation changes above the cave $[14,15] . \delta^{13} \mathrm{C}$ in a speleothem is governed by the sources of dissolved carbon in the drip water, which are atmospheric $\mathrm{CO}_{2}$, soil $\mathrm{CO}_{2}$, and carbonate bedrock, the relative contributions of which depend on the mechanisms controlling the bedrock dissolution and carbonate precipitation in the cave $[16,17] ; \delta^{13} \mathrm{C}$ of speleothems can be linked to climatedriven vegetation change when the most carbon in the deposited carbonate derives from soil $\mathrm{CO}_{2}$ under isotopic equilibrium; the contribution from the bedrock limestone and atmospheric $\mathrm{CO}_{2}$ are relatively insignificant. This is because $\delta^{13} \mathrm{C}$ of soil $\mathrm{CO}_{2}$ is controlled by the plant communities exhibiting significant variations in $\delta^{13} \mathrm{C}$. C3 plants like trees with $\delta^{13} \mathrm{C}$ value ranging from -19 to $-32 \%$ (average $-27 \%$ ) generally occur in cold and humid climates while $\mathrm{C} 4$ plants such as tropical grasses, with $\delta^{13} \mathrm{C}$ ranging from -9 to $-19 \%$ (average $-13 \%$ ) grow in warm and water-stressed conditions $[18,19]$. The soil $\mathrm{CO}_{2}$ under $\mathrm{C} 3$ and $\mathrm{C} 4$ vegetation has typical $\delta^{13} \mathrm{C}$ values of $-22 \%$ and $-8 \%$, respectively. Carbonate precipitated under isotopic equilibrium is enriched in ${ }^{13} \mathrm{C}$ by $\sim 10 \%$ with respect to soil $\mathrm{CO}_{2}$ at $25^{\circ} \mathrm{C}$ [20]. Therefore, speleothem precipitated under exclusively C3 and C4 vegetation should have $\delta^{13} \mathrm{C}$ values of $\sim-12 \%$ and +2 , respectively. This large difference allows the reconstruction of shifts in vegetation type from forests to grasslands and vice versa [21]. However, one difficulty could be that the $\delta^{13} \mathrm{C}$ of speleothem is the integrated and weighted average contribution from the $\mathrm{CO}_{2}$ of the whole soil column; the deeper soil $\mathrm{CO}_{2}$ could be thousands of years old, and, therefore, it is difficult to decipher any short term climate change using the $\delta^{13} \mathrm{C}$ of speleothems.

Possible kinetic isotope fractionation must be considered before interpreting $\delta^{13} \mathrm{C}$ variation in terms of paleoenvironmental changes, because this can override changes in organic productivity associated with the soil zone [22]. Evaporative conditions may lead to nonequilibrium fractionation causing a large variation in $\delta^{18} \mathrm{O}$ and a strong linear correlation between $\delta^{13} \mathrm{C}$ and $\delta^{18} \mathrm{O}[17,23] . \mathrm{CO}_{2}$ degassing in the unsaturated zone above the cave may lead to enrichment of ${ }^{13} \mathrm{C}$ in the deposited carbonate [24]. The kinetic fractionation, if happens during calcite precipitation, can be checked by the Hendy's test: both $\delta^{13} \mathrm{C}$ and $\delta^{18} \mathrm{O}$ would increase along a particular growth layer with distance from the central axis [17]. However, this is not a foolproof technique [25] as it is difficult to pick samples from a particular layer. Also kinetic effect may cause more enrichment at the farther distances from the central growth axis.

Unlike the speleothems growing in mainland India, which indicate past monsoon overland, those from the caves of Andaman and Nicobar Islands (Figure 1) can be a very good source to study the oceanic monsoon variability. Monsoon activity begins in the boreal summer from the southern hemisphere, and the Andamans are the first to get rainfall during the monsoon season. Likewise during the retreat of the monsoon in winter, they are the last to get rain. The monthly temperature and rainfall are shown in Figure 2.

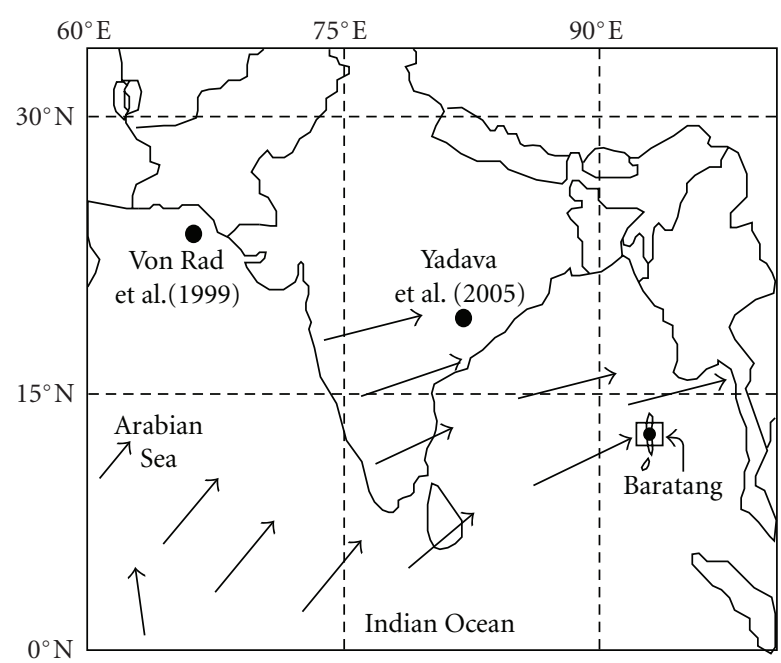

FIGURE 1: Location of the study site (Baratang) affected by southwest monsoon (arrows showing the wind direction during June-September). The approximate geographical locations of other paleomonsoon studies from the Arabian Sea and Indian subcontinent for comparison of regional trends in south west monsoon are shown by solid circles.

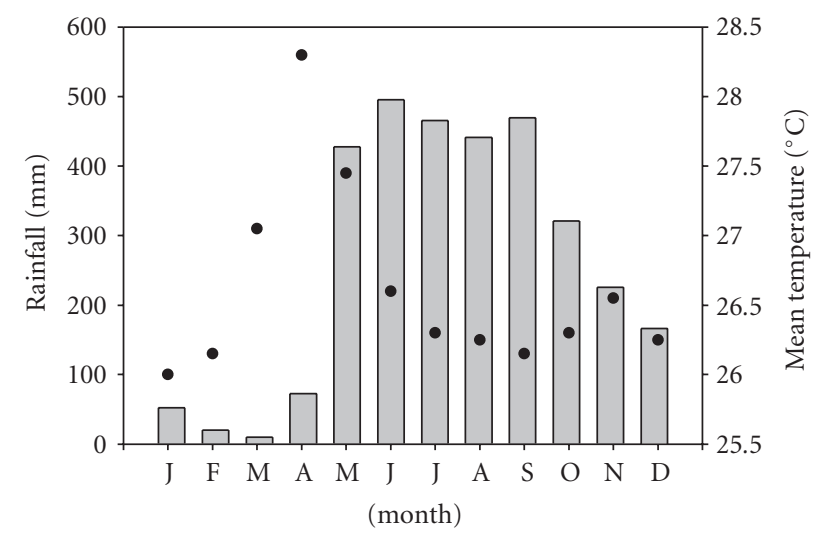

Figure 2: Mean monthly rainfall (grey bars, $\mathrm{mm}$ ) and temperature (filled circles ${ }^{\circ} \mathrm{C}$ ) at Port Blair, Andamans [30].

Further, the industrial pollution effects are smaller in the Andamans relative to mainland India.

We present here the first stable isotope records of a stalagmite from the Baratang cave of Andaman Islands, dated using radiocarbon. The aim was to detect (i) whether these samples are amenable to dating using ${ }^{14} \mathrm{C}$, (ii) Whether their oxygen isotopes indicate precipitation under isotopic equilibrium, and (iii) if (i) and (ii) above are true, can we reconstruct monsoon activity during the past few millennia?

\section{Dating Speleothems}

The best way to date is to count the annual layers [5] of actively growing speleothems. However, it is difficult to judge whether a speleothem is growing actively or not, especially if the collection is being made in the dry season. It is 
also more difficult to spot a speleothem with annual layers; for this, a rapidly growing speleothem in a region with high seasonal precipitation (e.g., monsoon) is necessary. The most widely used dating method for speleothems is using U-series, specifically "daughter deficiency" in ${ }^{230} \mathrm{Th} / \mathrm{U}$. A majority of speleothems behaves as a closed system with respect to uranium and its decay products. Dating is achieved using a Thermal Ionisation Mass Spectrometer (TIMS) [26, 27] or a Multi-Collector Inductively Coupled Plasma Mass Spectrometer (MC-ICP-MS) $[28,29]$. But for samples that are only a few millennia old, this could give results with large uncertainties because of contribution from detrital Th. Radiocarbon dating of speleothem is also useful for modern samples when the dilution due to dead carbon can be estimated [4]. One way to quantify the dead carbon is by using both ${ }^{230} \mathrm{Th} / \mathrm{U}$ and ${ }^{14} \mathrm{C}$ chronologies simultaneously [16].

\section{Materials and Methods}

3.1. Study Area and Present-Day Climate. The Baratang Island is located around $12^{\circ} 05^{\prime} \mathrm{N}, 92^{\circ} 45^{\prime} \mathrm{E}$ in the junction of middle and south Andaman, about $100 \mathrm{~km}$ north of Port Blair (Figure 3). A limestone cave of size $\sim 50 \mathrm{~m}$ with an elongated opening (height $\sim 10 \mathrm{~m}$, width $\sim 1 \mathrm{~m}$ ) housed speleothems. A stalagmite of length $\sim 20 \mathrm{~cm}$ was collected from the cave in 2005 . The present-day vegetation above the cave is dense tropical rain forest (C3 type) with a thin soil layer. The height of the cave above sea level is $\sim 18 \mathrm{~m}$. Meteorological data from Port Blair (the nearest available station to the cave site) shows that the present-day climate is humid with a mean annual precipitation of $3168 \mathrm{~mm}$ (average of 30 years from 1951-1980). The mean annual temperature and humidity are $26.6^{\circ} \mathrm{C}$ and $82 \%$, respectively [30].

3.2. Sampling and Analytical Methods. For stable isotope study, subsamples of about $1 \mathrm{mg}$ were collected along the growth direction of the stalagmite at an interval of about $2 \mathrm{~mm}$ using stainless steel drill bits of size $0.5 \mathrm{~mm}$. Each powdered sample was reacted with $100 \% \mathrm{H}_{3} \mathrm{PO}_{4}$ for $\sim 8$ hours at $25^{\circ} \mathrm{C}$. The $\mathrm{CO}_{2}$ produced was extracted, purified cryogenically, and analysed for $\delta^{13} \mathrm{C}$ and $\delta^{18} \mathrm{O}$ using dual-inlet stable isotope ratio mass spectrometer (GEO 20-20). A laboratory marble standard was run after every 10 measurements to check the reproducibility of measurements. The precision for the $\delta^{13} \mathrm{C}$ measurements, for the procedure followed, is better than $\pm 0.1 \%$ o [31]. The accuracy of the measurements is checked occasionally by running an international standard (NBS-19 supplied by IAEA), for which the long-term ( 5 years) average $\delta^{13} \mathrm{C}=1.95 \pm 0.08 \%$ and $\delta^{18} \mathrm{O}=-2.3$ $\pm 0.1 \%$ o (relative to PDB) (error at 2 sigma level). All the carbonate isotopic values are reported relative to the VPDB standard [32].

Rainwater samples were collected from the cave site during summer 2010 (from May to July). $\delta^{18} \mathrm{O}$ of water samples were measured using $\mathrm{CO}_{2}$ equilibration method [31]. All values are reported relative to VSMOW, and the analytical uncertainty was better than $0.1 \%$. For reproducibility check,

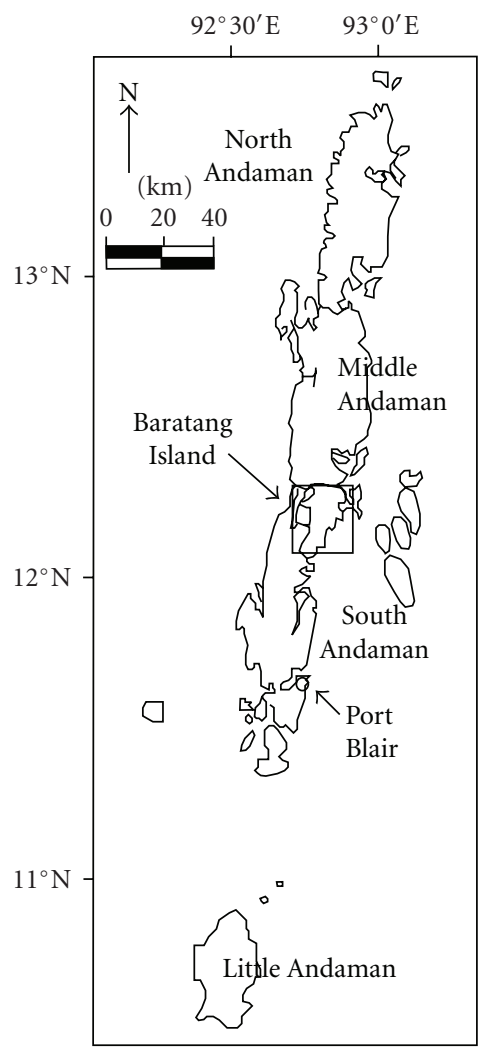

FIgURE 3: Map of Andaman Islands showing the location of Baratang Island.

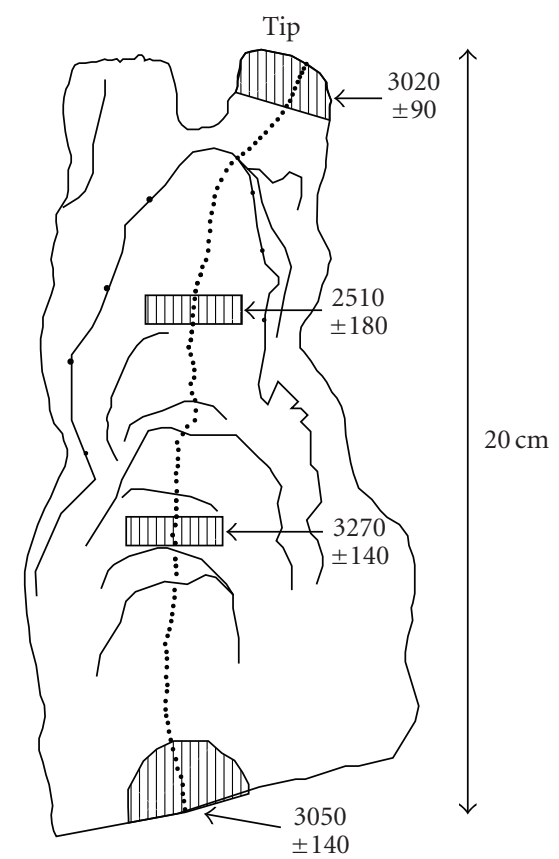

FIGURE 4: Sketch of the stalagmite showing the sampling for stable isotopes by dots and for radiocarbon dating by grey patches. Radiocarbon ages are also shown in years, with the corresponding uncertainty. 
TABLE 1: Uncalibrated radiocarbon dates of the stalagmite at various positions along the growth axis.

\begin{tabular}{lcc}
\hline Depth from tip $(\mathrm{mm})$ & Lab code & ${ }^{14} \mathrm{C}$ age $(\mathrm{yrs} \mathrm{BP}) \pm 1 \sigma$ \\
\hline $0-10$ & PRL-3014 & $3020 \pm 90$ \\
$70-77$ & PRL-3236 & $2510 \pm 180$ \\
$124-132$ & PRL-3237 & $3270 \pm 140$ \\
$185-205$ & PRL-3015 & $3050 \pm 140$ \\
\hline
\end{tabular}

some samples were repeated, and the results of the replicates were well within the uncertainty of measurements.

For radiocarbon dating, about 5-7 g of carbonate were taken from different parts of the stalagmite along its growth axis (shown as patches in Figure 4), reacted with $85 \% \mathrm{H}_{3} \mathrm{PO}_{4}$ to produce $\mathrm{CO}_{2}$ which was then quantitatively converted to benzene. The residual activity of the benzene was measured in a liquid scintillation counter (Quantulus LKB-1220). Further details of experimental procedures are discussed elsewhere [31].

\section{Results}

Four radiocarbon ages obtained for the stalagmite are shown in Figure 4 and Table 1. The ages are anomalous at the tip and the base; the ages are the same within $1 \sigma$ uncertainty of radiocarbon ages. Therefore, the speleothem must have grown during the past few millennia. More precise dating could be possible by U-Th mass spectrometry, but only for older samples.

To check if any kinetic fractionation had occurred during the calcite precipitation, we performed the Hendy's test (Figure 5). There are no significant trends obtained in the $\delta^{18} \mathrm{O}$ indicating that the oxygen isotopic equilibrium between calcite and drip water was maintained during stalagmite precipitation. A little enrichment in $\delta^{13} \mathrm{C}$ (Figure 5(a)) on both sides of the central axis shows a little kinetic fractionation during the degassing of $\mathrm{CO}_{2}$ leading to an enrichment in ${ }^{13} \mathrm{C}$ in the residual carbonate. Also, the plot between $\delta^{13} \mathrm{C}$ and $\delta^{18} \mathrm{O}$ (Figure $5(\mathrm{~b})$ ) does not show a strong correlation (not significant at 0.01 level) indicating limited evaporation during stalagmite deposition. This is not surprising as the island is close to the sea and the cave is likely humid for most of the year.

A total of 91 stable isotope measurements were carried out on the stalagmite. The $\delta^{18} \mathrm{O}$ values of rain water collected between May to July, 2010 are shown in Figure 6. They vary between 0.7 to $-5.2 \%$ with respect to VSMOW. The relationship between fractionation factor $\left(\alpha_{c-w}\right)$ and temperature at which calcite precipitates is given by the following equation [33]:

$$
10^{3} \ln \alpha_{c-w}=\frac{2.78 \times 10^{6}}{T^{2}}-3.39,
$$

where $\alpha_{c-w}=\left({ }^{18} o /{ }^{16} o\right)_{\text {calcite }} /\left({ }^{18} o /{ }^{16} o\right)_{\text {water }}, T$ is the temperature in Kelvin. At $26.6^{\circ} \mathrm{C}$, the fractionation factor $\alpha_{c-w}=1.02796$ and hence enrichment factor $(\alpha-1) 10^{3}=$ $\varepsilon=27.96 \%$. Thus, carbonate precipitated under isotopic

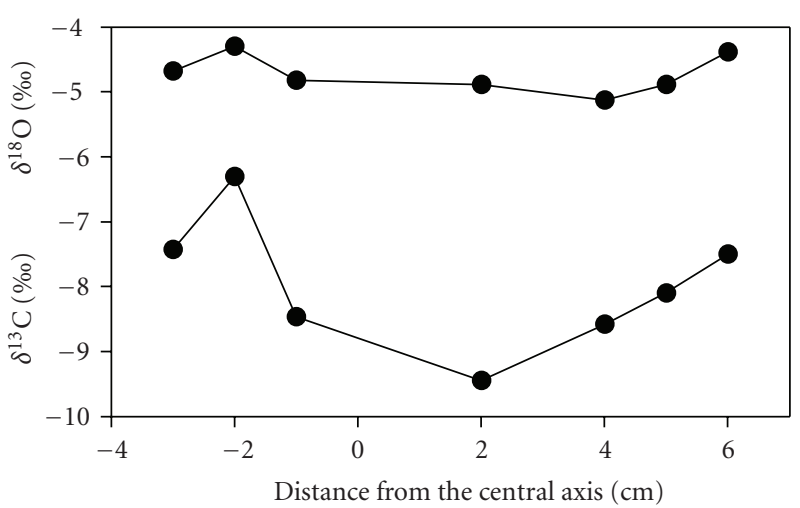

(a)

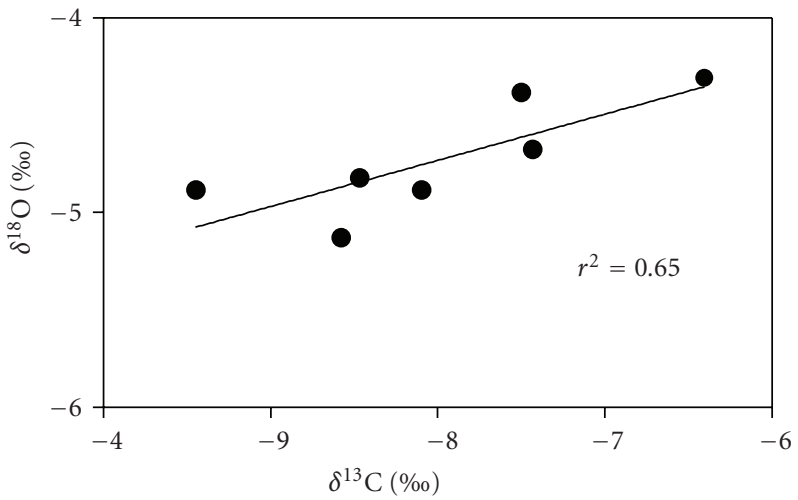

(b)

Figure 5: $\delta^{18} \mathrm{O}$ and $\delta^{13} \mathrm{C}$ plotted along a single layer to check if any trend exists along a layer due to kinetic fractionation caused by evaporation and rapid degassing during calcite precipitation. $\delta^{18} \mathrm{O}$ $\delta^{13} \mathrm{C}$ correlation is shown below in (b).

equilibrium with rain water should be enriched by $\sim 28 \%$. Considering $\delta^{18} \mathrm{O}$ of rain water varying between 0.7 to $-5.2 \%$ with respect to VSMOW, the stalagmite $\delta^{18} \mathrm{O}$ should vary between 28.7 to $22.5 \%$, relative to the same standard, VSMOW. The relation between $\delta^{18} \mathrm{O}$ of the VSMOW and PDB standards are given by $[34,35]$

$$
\begin{aligned}
& \delta^{18} \mathrm{O}_{\text {VSMOW }}=1.03091\left(\delta^{18} \mathrm{O}_{\mathrm{VPDB}}\right)+30.91, \\
& \delta^{18} \mathrm{O}_{\mathrm{VPDB}}=0.97002\left(\delta^{18} \mathrm{O}_{\text {VSMOW }}\right)-29.98 .
\end{aligned}
$$

It is observed that the $\delta^{18} \mathrm{O}$ of stalagmite (Figure 7) mostly varies between -4 and $-6 \%$ relative to PDB. Using the above relations, we get stalagmite $\delta^{18} \mathrm{O}$ relative to VSMOW varies between 26.8 and $24.7 \%$ o which is well within the predicted range for the present-day calcite precipitating under isotopic equilibrium. Therefore, the southwest monsoon in the past few millennia was quite similar to that at present. Small variations in $\delta^{18} \mathrm{O}$ shows little change in the mean annual precipitation throughout the deposition history.

$\delta^{13} \mathrm{C}$ also shows very little variation throughout the deposition history except at the tip. The $\delta^{13} \mathrm{C}$ value lies between -10 and $-12 \%$ for most of the samples while it is somewhat higher at the tip. 


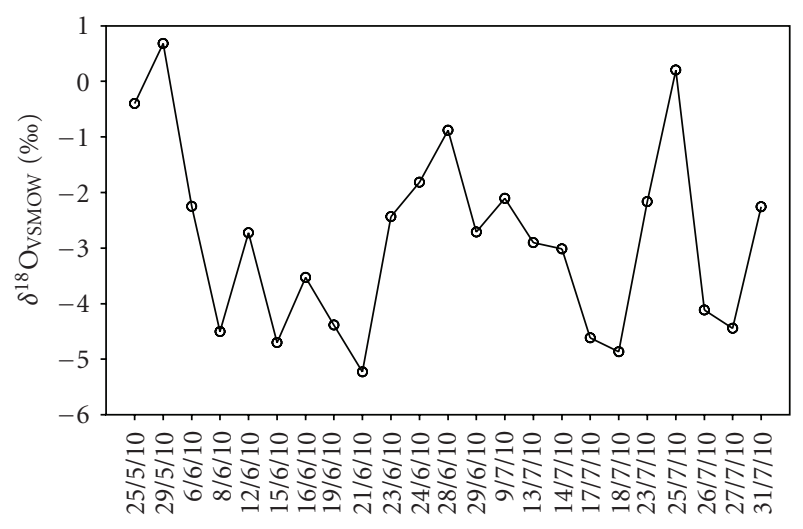

Date of collection

FIGURE 6: Variation in $\delta^{18} \mathrm{O}$ of rain water collected in summer 2010 (May to July).

\section{Discussion}

Fast growing speleothems are suitable for the high-resolution paleomonsoon reconstruction. Such speleothems could be useful for the reconstruction of annual and even seasonal rainfall variations in the past. Unpredictable dead carbon contribution makes it difficult to date a speleothem using the ${ }^{14} \mathrm{C}$ method. Dead carbon is the carbon present in the speleothem that originated from the old (typically millions of years) limestone bedrock having no radiocarbon. Therefore, the ${ }^{14} \mathrm{C}$ age of speleothem is overestimated (the reservoir effect [36]). In the case of an actively growing speleothem, the dead carbon contribution can be estimated using the tip age, because of the presence of bomb carbon (e.g., [5]). Assuming constant dead carbon contribution throughout the calcite deposition, a chronology can be established [5, 37]. However, the assumption of constant dead carbon contribution needs to be checked. The ages of the stalagmite listed in Table 1 show an anomalous behaviour, varying from 2500 to 3200 yrs BP (uncalibrated ages). This could be due to the changes in the dead carbon contribution during stalagmite deposition. Such material could also cause problems in U-Th dating because the increase in detrital matter introduces large errors. Yadava et al. [5] estimated -880 and $-1230 \mathrm{yr}$ as age corrections for the addition of dead carbon in two stalagmites from Central India. Hendy et al. [17] estimated corrections of 530-715 yrs in a stalagmite and 775$880 \mathrm{yrs}$ in another from Villars cave, southwest France and Han-sur-Lesse cave, Belgium, respectively. Yanjun et al. [38] showed a dead carbon fraction of $10-15 \%$ in a stalagmite from Shihua Cave, Beijing, leading to an age overestimation of 928-1500yrs. From all these comparisons we conclude that the dead carbon contribution is not more than $15 \%$ in most cases, for samples of recent geological age. Therefore, the dead carbon could have overestimated radiocarbon ages by $1000-1500$ years in the present sample.

$\delta^{18} \mathrm{O}$ for the present stalagmite mostly ranges between -4 and $-6 \%$ excluding a few sharp peaks (Figure 7 ). By and large, we can conclude that the rainfall fluctuations were not more than $200 \mathrm{~mm}$ during the past few millennia, assuming

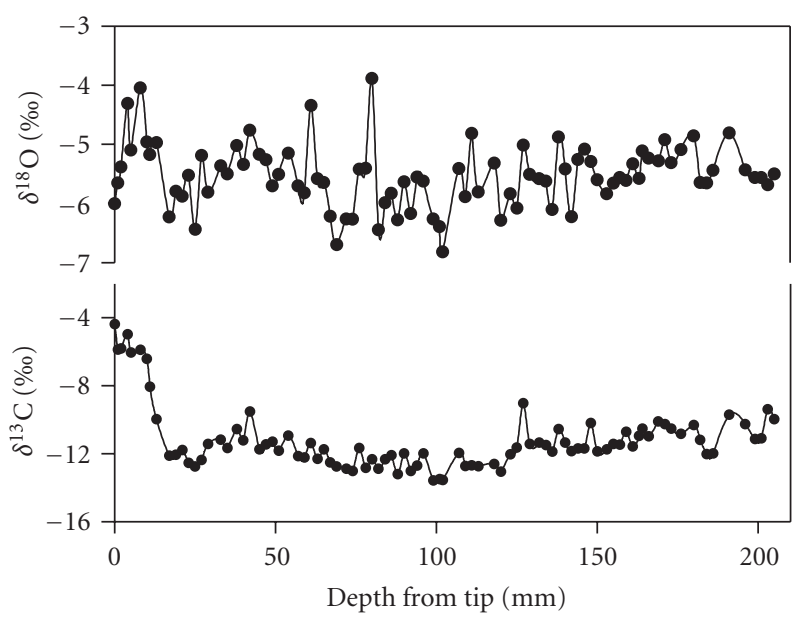

FIGURE 7: $\delta^{18} \mathrm{O}$ and $\delta^{13} \mathrm{C}$ versus depth along the growth direction of the stalagmite.

an amount effect of $-1.5 \%$ per $100 \mathrm{~mm}$ increase of rain [5, 36].

A comparison with other paleomonsoon proxy records from regions affected by ISM is shown in Figure 8. The comparison is made only for the period 3200-2500yrs BP, the approximate growth period of the stalagmite and for more recent time to compare with the present-day monsoon. Yadava and Ramesh [4] reconstructed the southwest monsoon rainfall variation for the last $\sim 3400$ yrs based on a stalactite $\delta^{18} \mathrm{O}$ from Orissa (location shown in Figure 1), and this is compared with the present results (Figure $8(\mathrm{~A})$ and $8(\mathrm{~B})$ ). The monsoon prior to $2500 \mathrm{yrs} \mathrm{BP}$ was similar to that of the last $0-400 \mathrm{yrs}$, a similar finding with the present stalagmite. However, there was a large variation in monsoon between 2100-1500yrs (not shown in Figure 8(A)). Von Rad et al. [39] reconstructed a high-resolution ( $\sim 7 \mathrm{yr})$ paleomonsoon record using thickness variations in the varved sediments collected from the northern Arabian Sea (for location, see Figure 1). The varve thickness is controlled by precipitation and river runoff, and, hence, the variability in varve thickness was interpreted as a proxy for past rainfall variations [40]. Lower thickness of the varved sediments is associated with the lower discharge from the Indus river and vice versa. A comparison of varve thickness variation with stalagmite $\delta^{18} \mathrm{O}$ from the Baratang Island is shown in (Figure $8(\mathrm{C})$ and $8(\mathrm{~B})$ ). Though there were variations in monsoon recorded in the varved sediments between 2500 and 400 yrs BP, but the monsoon after 400 yrs BP is similar to that present between $3200-2500$ yrs BP (Figure $8(\mathrm{C})$ ).

$\delta^{13} \mathrm{C}$ in the stalagmite mostly varies between -11 and $-13 \%$, a dominant C3 signature since carbonate precipitated under equilibrium with soil $\mathrm{CO}_{2}$ under $\mathrm{C} 3$ vegetation should have $\delta^{13} \mathrm{C}$ value around $-12 \%$ at $\sim 26^{\circ} \mathrm{C}$ (the mean annual temperature). The bedrock carbonate $\left(\delta^{13} \mathrm{C} \sim 0 \%\right.$ o contribution shifts the calcite $\delta^{13} \mathrm{C}$ values towards more positive values. Therefore, the bedrock carbon contribution is not very high in the stalagmite except at the tip. A gradual enrichment in ${ }^{13} \mathrm{C}$ towards the tip shows an apparently larger bedrock contribution. The possibility of shift in vegetation 


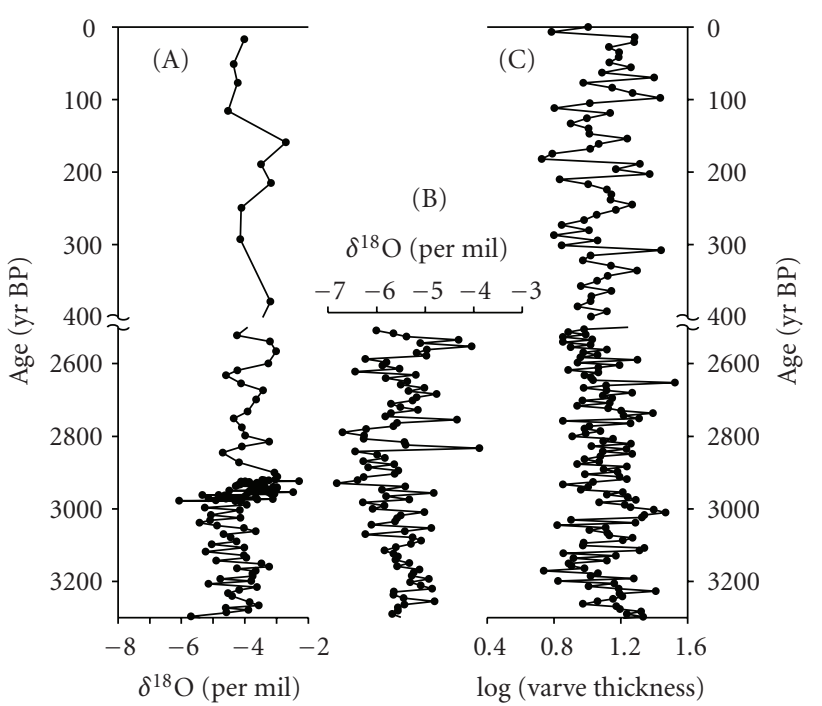

FIGURE 8: Comparison with other precisely dated paleomonsoon records from various geographical regions influenced by ISM. The data is presented for $3300-2500 \mathrm{yrs}$ and the recent $\sim 400 \mathrm{yrs}$ BP. (A) stalactite $\delta^{18} \mathrm{O}$ from the Gupteswar cave, Central India [4], (B) $\delta^{18} \mathrm{O}$ variation in stalagmite from Baratang (this study). The data is compared in the approximate age range of 2500-3300 yrs. (C) varve thickness variation from sediment core from northern Arabian Sea [39].

from $\mathrm{C} 3$ to $\mathrm{C} 4$ at the later phase of the stalagmite growth cannot be ruled out. Probably tropical grasses (C4) grew at the surface causing enriched ${ }^{13} \mathrm{C}$ in the stalagmite carbonate. But this is less probable as there is no major change in the precipitation (inference based on $\delta^{18} \mathrm{O}$ ) observed during this time to cause a water-stressed condition. Therefore, we speculate that the ${ }^{13} \mathrm{C}$ enrichment at the tip was caused by apparent higher bedrock contribution because of lesser soil $\mathrm{CO}_{2}$. This needs further work and verification.

\section{Conclusions}

This is the first isotopic study of speleothems reported from Andamans. The summer monsoon over the Andaman Islands was similar to the present a few millennia ago; the southwest monsoon was the main source of annual precipitation. The radiocarbon dating of speleothem has highlighted problems associated with incorporation of an unknown proportion of dead carbon during calcite precipitation.

\section{Acknowledgments}

The authors thank ISRO-GBP for funding and Mr. Felix for collecting samples of rainwater at Andamans. The authors are grateful to Professor M. S. Srinivasan for kindling our interest by sending us excellent photographs of the Andaman caves and Dr. J. S. Ray for help during field work.

\section{References}

[1] B. Parthasarathy, A. A. Munot, and D. R. Kothawale, "All-India monthly and seasonal rainfall series: 1871-1993," Theoretical and Applied Climatology, vol. 49, no. 4, pp. 217-224, 1994.

[2] D. Fleitmann, S. J. Burns, U. Neff, M. Mudelsee, A. Mangini, and A. Matter, "Palaeoclimatic interpretation of high-resolution oxygen isotope profiles derived from annually laminated speleothems from Southern Oman," Quaternary Science Reviews, vol. 23, no. 7-8, pp. 935-945, 2004.

[3] M. G. Yadava and R. Ramesh, "Past rainfall and trace element variations in a tropical speleothem from India," Mausam, vol. 52, pp. 307-316, 2001.

[4] M. G. Yadava and R. Ramesh, "Monsoon reconstruction from radiocarbon dated tropical Indian speleothems," The Holocene, vol. 15, no. 1, pp. 48-59, 2005.

[5] M. G. Yadava, R. Ramesh, and G. B. Pant, "Past monsoon rainfall variations in peninsular India recorded in a 331-year-old speleothem," The Holocene, vol. 14, no. 4, pp. 517-524, 2004.

[6] L. G. Thompson, T. Yao, M. E. Davis et al., "Tropical climate instability: the last glacial cycle from a Qinghai-Tibetan ice core," Science, vol. 276, no. 5320, pp. 1821-1825, 1997.

[7] S. R. Managave, M. S. Sheshshayee, R. Ramesh, H. P. Borgaonkar, S. K. Shah, and A. Bhattacharyya, "Response of cellulose oxygen isotope values of teak trees in differing monsoon environments to monsoon rainfall," Dendrochronologia, vol. 29, no. 2, pp. 89-97, 2011.

[8] D. M. Anderson, J. T. Overpeck, and A. K. Gupta, "Increase in the Asian southwest monsoon during the past four centuries," Science, vol. 297, no. 5581, pp. 596-599, 2002.

[9] M. Tiwari, R. Ramesh, R. Bhushan et al., "Did the Indo-Asian summer monsoon decrease during the Holocene following insolation?" Journal of Quaternary Science, vol. 25, no. 7, pp. 1179-1188, 2010.

[10] M. Tiwari, R. Ramesh, B. L. K. Somayajulu, A. J. T. Jull, and G. S. Burr, "Early deglacial ( 19-17 ka) strengthening of the northeast monsoon," Geophysical Research Letters, vol. 32, no. 19, pp. 1-4, 2005.

[11] R. Ramesh, M. Tiwari, S. Chakraborty, S. Managave, M. G. Yadava, and D. K. Sinha, "Retrieval of south Asian monsoon variation during the Holocene form natural climate archives," Current Science, vol. 99, no. 12, pp. 1770-1786, 2010.

[12] M. Bar-Matthews, A. Ayalon, A. Kaufman, and G. J. Wasserburg, "The Eastern Mediterranean paleoclimate as a reflection of regional events: soreq cave, Israel," Earth and Planetary Science Letters, vol. 166, no. 1-2, pp. 85-95, 1999.

[13] W. C. Francisco Jr., S. J. Burns, I. Karmann, W. D. Sharp, M. Vuille, and J. A. Ferrari, "A stalagmite record of changes in atmospheric circulation and soil processes in the Brazilian subtropics during the Late Pleistocene," Quaternary Science Reviews, vol. 25, no. 21-22, pp. 2749-2761, 2006.

[14] J. A. Dorale, "Climate and vegetation history of the midcontinent from 75 to $25 \mathrm{ka}$ : a speleothem record from Crevice Cave, Missouri, USA," Science, vol. 282, no. 5395, pp. 18711874, 1998.

[15] D. Genty, D. Blamart, R. Ouahdi et al., "Precise dating of Dansgaard-Oeschger climate oscillations in western Europe from stalagmite data," Nature, vol. 421, no. 6925, pp. 833-837, 2003.

[16] D. Genty, A. Baker, M. Massault et al., "Dead carbon in stalagmites: carbonate bedrock paleodissolution vs. ageing of soil organic matter. Implications for ${ }^{13} \mathrm{C}$ variations in speleotherms," Geochimica et Cosmochimica Acta, vol. 65, no. 20, pp. 3443-3457, 2001. 
[17] C. H. Hendy, "The isotopic geochemistry of speleothemsI. The calculation of the effects of different modes of formation on the isotopic composition of speleothems and their applicability as palaeoclimatic indicators," Geochimica et Cosmochimica Acta, vol. 35, no. 8, pp. 801-824, 1971.

[18] P. Deines, "The isotopic composition of reduced organic carbon," in Handbook of Environmental Isotope Geochemistry, 1, P. Fritz and J. C. Fontes, Eds., The Terrestrial Environment, pp. 329-406, Elsevier, Amsterdam, The Netherlands, 1980.

[19] G. D. Farquhar, J. R. Ehleringer, and K. T. Hubick, "Carbon isotope discrimination and photosynthesis," Annual Review of Plant Physiology, vol. 40, pp. 503-537, 1989.

[20] T. E. Cerling, "The stable isotopic composition of modern soil carbonate and its relationship to climate," Earth and Planetary Science Letters, vol. 71, no. 2, pp. 229-240, 1984.

[21] A. H. Laskar, N. Sharma, R. Ramesh, R. A. Jani, and M. G. Yadava, "Paleoclimate and paleovegetation of Lower Narmada Basin, Gujarat, Western India, inferred from stable carbon and oxygen isotopes," Quaternary International, vol. 227, pp. 183$189,2010$.

[22] C. Spötl, I. J. Fairchild, and A. F. Tooth, "Cave air control on dripwater geochemistry, Obir Caves (Austria): implications for speleothem deposition in dynamically ventilated caves," Geochimica et Cosmochimica Acta, vol. 69, no. 10, pp. 24512468, 2005.

[23] H. Linge, S. E. Lauritzen, J. Lundberg, and I. M. Berstad, "Stable isotope stratigraphy of Holocene speleothems: examples from a cave system in Rana, northern Norway," Palaeogeography, Palaeoclimatology, Palaeoecology, vol. 167, no. 3-4, pp. 209-224, 2001.

[24] A. Baker, E. Ito, P. L. Smart, and R. F. McEwan, "Elevated and variable values of $\delta^{13} \mathrm{C}$ in speleothems in a British cave system," Chemical Geology, vol. 136, no. 3-4, pp. 263-270, 1997.

[25] J. A. Dorale and Z. Liu, "Limitations of hendy test criteria in judging the paleoclimatic suitability of speleothems and the need for replication," Journal of Cave and Karst Studies, vol. 71, no. 1, pp. 73-80, 2009.

[26] R. L. Edwards, J. H. Chen, and G. J. Wasserburg, " ${ }^{238} \mathrm{U}^{234} \mathrm{U}-$ ${ }^{230} \mathrm{Th}$ systematics and the precise measurement of time over the last 500,000 years," Earth and Planetary Science Letters, vol. 81, pp. $175-192,1988$.

[27] W. X. Li, J. Lundberg, A. P. Dickin et al., "High-precision massspectrometric uranium-series dating of calcite deposits and implications for palaeoclimatic studies," Nature, vol. 339, pp. 534-536, 1989.

[28] D. A. Richards and J. A. Dorale, "Uranium-series chronology and environmental applications of speleothems," in Reviews in Mineralogy and Geochemistry, B. Bourdon, G. M. Henderson, C. C. Lundstrom, and S. P. Turner, Eds., vol. 52 of Uranium Series Geochemistry, pp. 407-460, Mineralogical Society of America, Washington, Wash, USA, January 2003.

[29] C. C. Shen, R. Lawrence Edwards, H. Cheng et al., "Uranium and thorium isotopic and concentration measurements by magnetic sector inductively coupled plasma mass spectrometry," Chemical Geology, vol. 185, no. 3-4, pp. 165-178, 2002.

[30] India Meteorology Department, Climatological Tables of Observatories in India 1951 1980, National Data Centre, New Delhi, India, 1999.

[31] M. G. Yadava and R. Ramesh, "Speleothems-Useful proxies for past monsoon rainfall," Journal of Scientific and Industrial Research, vol. 58, no. 5, pp. 339-348, 1999.

[32] R. Gonfiantini, "The $\delta$-notation and the mass-spectrometric measurement techniques," in Stable Isotope Hydrology: Deuterium and Oxygen-18 in the Water Cycle, J. R. Gat and R.
Gonfiantini, Eds., Technical Report Series 210, IAEA, Vienna, Austria, 1981.

[33] J. R. O’Neil, R. N. Clayton, and T. K. Mayeda, "Oxygen isotope fractionation in divalent metal carbonates," The Journal of Chemical Physics, vol. 51, no. 12, pp. 5547-5558, 1969.

[34] I. Clark and P. Fritz, Environmental Isotopes in Hydrology, Lewis, New York, NY, USA, 1997.

[35] Z. Sharp, Principles of Stable Isotope Geochemistry, Prentice Hall, Upper Saddle River, NJ, USA, 2007.

[36] W. G. Mook, "Carbon-14 in hydrological studies," in Handbook of Environmental Isotope Geochemistry, 1, P. Fritz and J. C. Fontes, Eds., The Terrestrial Environment, pp. 49-74, Elsevier, Amsterdam, The Netherlands, 1980.

[37] P. W. Williams, A. Marshall, D. C. Ford, and A. V. Jenkinson, "Palaeoclimatic interpretation of stable isotope data from Holocene speleothems of the Waitomo District, North Island, New Zealand," The Holocene, vol. 9, no. 6, pp. 649-657, 1999.

[38] C. Yanjun, W. Beck, P. Zicheng, and Z. Zhaofeng, "Effect of dead carbon on the ${ }^{14} \mathrm{C}$ dating of the speleothem," Chinese Science Bulletin, vol. 50, no. 8, pp. 817-821, 2005.

[39] U. Von Rad, M. Schaaf, K. H. Michels, H. Schulz, W. H. Berger, and F. Sirocko, "A 5000-yr record of climate change in varved sediments from the oxygen minimum zone off Pakistan, Northeastern Arabian Sea," Quaternary Research, vol. 51, no. 1, pp. 39-53, 1999.

[40] A. Lückge, H. Doose-Rolinski, A. A. Khan, H. Schulz, and U. Von Rad, "Monsoonal variability in the northeastern Arabian Sea during the past 5000 years: geochemical evidence from laminated sediments," Palaeogeography, Palaeoclimatology, Palaeoecology, vol. 167, no. 3-4, pp. 273-286, 2001. 

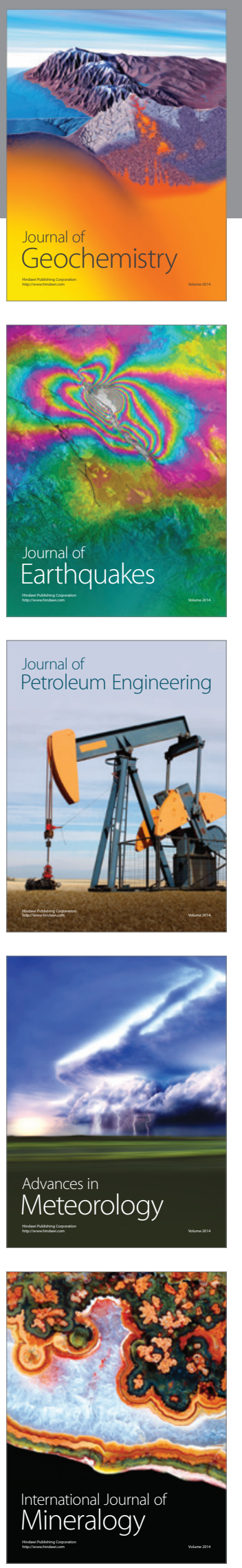
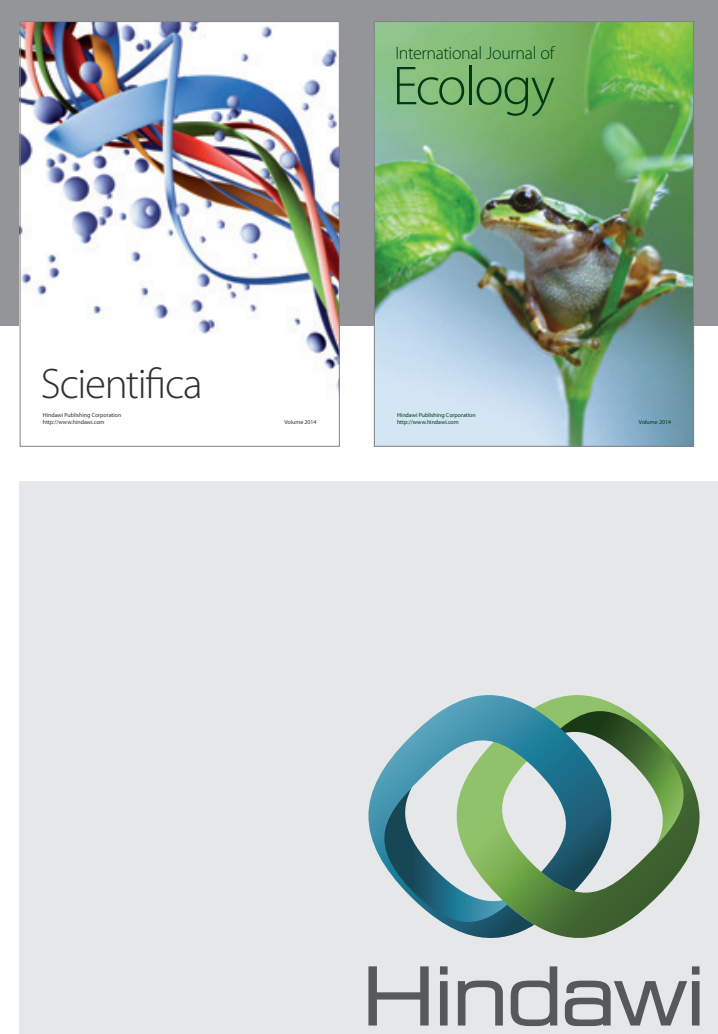

Submit your manuscripts at http://www.hindawi.com
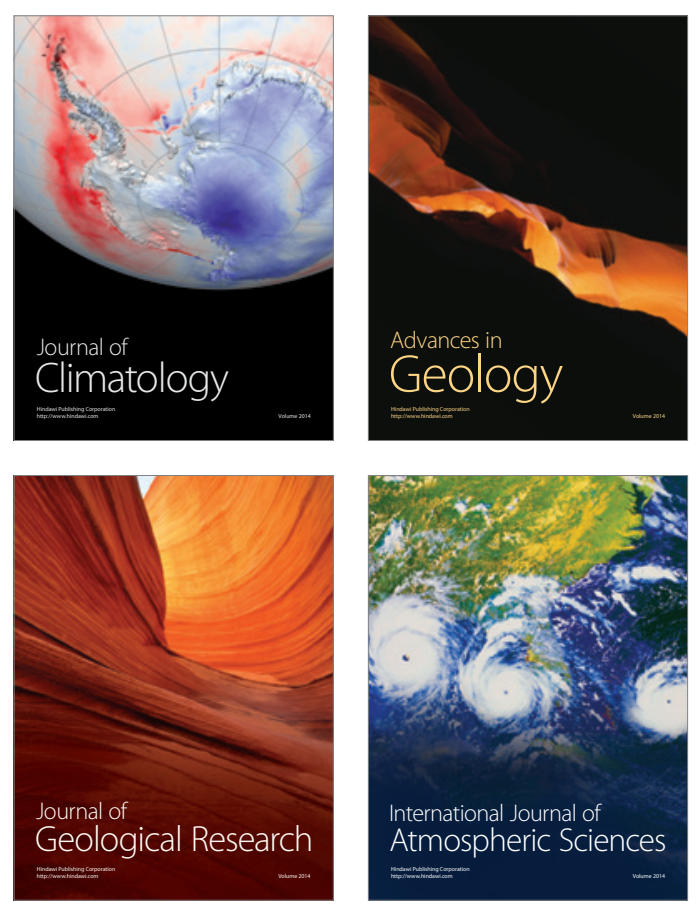
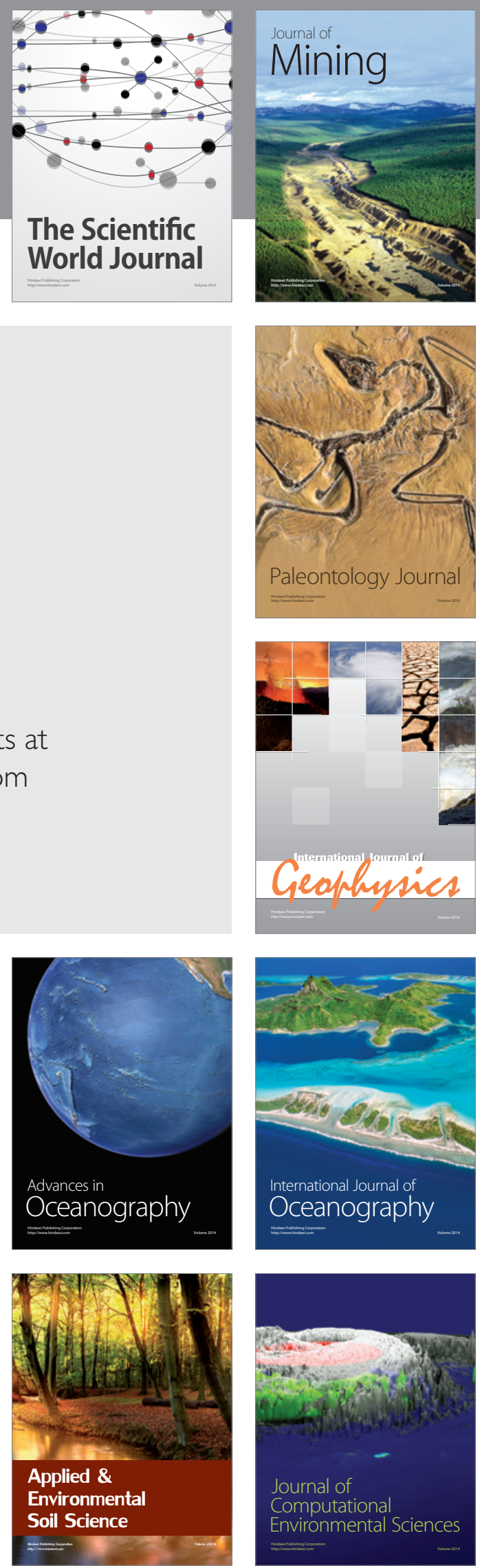